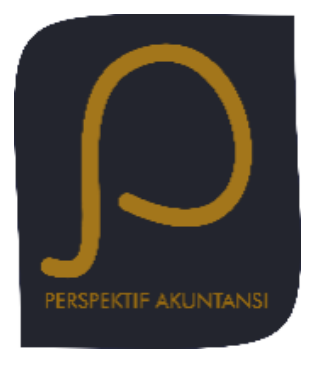

Perspektif Akuntansi

Volume 1 Nomor 1 (Oktober 2018), hal. 01-19

ISSN: 2623-0194(Print), 2623-0186(Online) Copyright(C) The Authors(s). All Rights Reserved

Fakultas Ekonomika dan Bisnis,

Universitas Kristen Satya Wacana

DOI: https://doi.org/10.24246/persi.v1i1.p1-19

http://ejournal.uksw.edu/persi

\title{
Laba Komprehenif vs Laba Bersih: Manakah yang Lebih Relevan?
}

\author{
Ayu Fina Karimatussofiah \\ Fakultas Ekonomika dan Bisnis, Universitas Kristen Satya Wacana \\ Ari Budi Kristanto ${ }^{1}$ \\ Fakultas Ekonomika dan Bisnis, Universitas Kristen Satya Wacana
}

\begin{abstract}
Received Abstract. This research aims to analyze whether net income or 21/03/2018 comprehensive income contain higher relative value relevance. Implementation of comprehensive income report have been obligated Accepted by PSAK 1 revision 2009 as the IFRS on PSAK Indonesia since 2012, 05/07/2018 particularly about the disclosure of the other comprehensive income on the company's income statement. This study uses secondary data taken from companies' annual financial statement for the period of 2011 until 2016. The population are manufacturi companies, which are listed on Indonesian Stock Exchange for the period 2011-2016. This research uses 50 companies sorted by some criteria: companies that report their financial statement for all years, and companies that provide required data in this study. The result shows that both net income and comprehensive income are positively influence the stock price. It means that both of net income and comprehensive income contain relative value relevance, out of the control variables provide (Return on Equity, Book Value per Share, and Company size). Another result is the relative value relevance of comprehensive income is higher than relative value relevance of net income.
\end{abstract}

Keywords: Relative value relevance, IFRS adoption, net income, comprehensive income, stock price

\footnotetext{
${ }^{1}$ ari.kristanto@staff.uksw.edu
} 


\begin{abstract}
Abstrak. Penelitian ini bertujuan untuk menganalisis apakah relevansi nilai relatif laba komprehensif lebih besar dari relevansi nilai relatif laba bersih. Pelaporan laba komprehensif diatur dalam PSAK 1 revisi 2009 sebagai konsekuensi penerapan IFRS ke dalam PSAK. Penelitian ini menggunakan data sekunder yang bersumber dari laporan keuangan tahunan perusahaan selama tahun 20112016. Sampel penelitian dipilih dengan menggunakan kriteria khusus, yaitu perusahaan yang melaporkan laporan keuangannya secara lengkap setiap 31 Desember, serta perusahaan yang menyediakan data lain yang dibutuhkan dalam penelitian. Populasi penelitian ini adalah perusahaan dalam industri manufaktur di Bursa Efek Indonesia pada tahun 2011-2016, dengan sampel sebanyak 50 perusahaan. Hasil dari penelitian ini menunjukkan baik laba bersih maupun laba komprehensif memiliki pengaruh positif dan signifikan terhadap harga saham perusahaan, sehingga keduanya memiliki relevansi nilai relatif di luar variabel kontrol (Return on Equity, Book Value per Share, dan ukuran perusahaan). Hasil lainya adalah relevansi nilai relatif laba komprehensif lebih besar dari relevansi nilai relatif laba bersih.
\end{abstract}

Kata kunci: Relevansi nilai relatif, konvergensi IFRS, laba bersih, laba komprehensif, harga saham

\title{
Pendahuluan
}

Laporan keuangan merupakan media komunikasi perusahaan untuk menunjukkan kondisi keuangannya selama periode waktu tertentu kepada pemangku kepentingan dalam rangka pengambilan keputusan. Salah satu upaya memastikan relevansi laporan keuangan dalam pengambilan keputusan adalah pelaporan berbasis standar yang berkualitas (Syagata \& Daljono, 2014).

Salah satu informasi utama dalam pelaporan keuangan yaitu laba. Angka laba yang dilaporkan dalam laporan laba rugi merepresentasikan pencapaian kinerja perusahaan dalam periode waktu tertentu. Angka laba penting bagi berbagai pengguna laporan keuangan baik itu investor, kreditur, pemerintah maupun pihak lain yang berkepentingan dengan perusahaan untuk mampu menilai kinerja. Laporan laba rugi dapat bermanfaat untuk melakukan evaluasi kinerja historis, dasar prediksi kinerja kemudian, serta menilai risiko diperolehnya kas bersih di kemudian hari.

Bagi investor, laporan laba rugi memberikan informasi mengenai laba bersih yang diperhatikan investor untuk menilai kemampuan menghasilkan laba per lembar saham. Melalui angka laba, investor mampu memiliki gambaran tentang kinerja. Perusahaan dengan kinerja tinggi (angka laba tinggi) dapat menarik minat investor untuk membeli saham perusahaan.

Sejak dilakukannya konvergensi International Financial Reporting Standards (IFRS) pada masa 2008-2011 di Indonesia, Pernyataan Standar Akuntansi 
Keuangan (PSAK) yang mengatur pelaporan keuangan di Indonesia mengalami beberapa perkembangan. Salah satunya adalah dengan diberlakukannya PSAK 1 Revisi 2009 dengan perubahannya yang siginifikan yaitu munculnya kewajiban membuat Laporan Laba Rugi Komprehensif sebagai pelengkap dari Laporan Laba Rugi. Namun pada tahun 2013 peraturan tersebut kembali direvisi oleh Ikatan Akuntan Indonesia (IAI), Laporan Laba Rugi Komprehensif direvisi menjadi Laporan Laba Rugi dan Penghasilan Komprehensif Lain. Selain perubahan nama, terdapat pembaruan susunan laporan dengan membedakan pos/akun yang akan direklasifikasikan ke laporan laba rugi dengan yang tidak akan dilaporkan sebagai laba rugi. Hal tersebut mengakibatkan munculnya pos laba komprehensif yang dapat dijadikan sebagai pertimbangan baru bagi para pengguna laporan keuangan.

Menurut Bragg (2012), total penghasilan komprehensif merupakan gabungan antara laba rugi serta penghasilan komprehensif lain. Penghasilan komprehensif diperoleh dari laba bersih setelah dipengaruhi oleh pos-pos penghasilan dan beban yang tidak tercatat dalam laporan laba rugi. Pos-pos tersebut tidak ada hubungannya dengan kegiatan operasi normal perusahaan, sehingga memberikan informasi yang lebih wajar terkait laba perusahaan. Penelitian terdahulu yang dilakukan oleh Lin, Martinez, Wang dan Yang (2016) serta Khan, Bradbury dan Courtenay (2017) menyatakan bahwa investor saat ini lebih menghargai informasi dalam laporan laba rugi komprehensif.

Sinarto dan Christiawan (2014) membuktikan bahwa nilai relevansi laba komprehensif lebih tinggi dibandingkan laba bersih. Hal ini mengindikasikan adanya hasil yang sejalan dengan penelitian-penelitian terkait laba komprehensif lainnya, seperti penelitian Lin, Martinez dan Wang (2016), Devalle (2012), serta Kanagaretnam, Mathieu dan Shehata (2009) yang menyatakan bahwa laba komprehensif lebih relevan dalam pertimbangan investor dibandingkan dengan laba bersih. Penelitian serupa belum terlalu banyak dilaksanakan di Indonesia, antara lain penelitian Sinarto dan Christiawan (2014) serta Yudiman, Ahmar dan Darmansyah (2017).

Penelitian sebelumnya masih memiliki keterbatasan, dengan hanya fokus pada 50 perusahaan paling besar nilai kapitalisasi pasar serta nilai perdagangan sahamnya (Sinarto \& Christiawan, 2014). Hal ini menjadi motivasi untuk diteliti kembali dengan cakupan sampel yang lebih luas. Penelitian Yudiman, Ahmar dan Darmansyah (2017) juga menarik untuk dikembangkan. Penelitian tersebut memodelkan variabel Net Income (NI) dan Comprehensive Income (CI) bersama-sama sebagai variabel bebas. Model ini memiliki risiko bias karena CI sendiri antara lain terbentuk dari komponen NI. Penelitian kali ini mencoba membandingkan relevansi NI dan CI melalui model yang terpisah, sehingga diharapkan dapat membantu memperbandingkan relevansi nilai masing- 
masing secara relatif. Penelitian kali ini menggunakan periode yang lebih panjang dibandingkan penelitian yang sebelumnya, yaitu selama tahun 20112016 ketika pasar sudah semakin terbiasa dengan format pelaporan yang baru, sehingga evaluasi dalam jangka yang lebih panjang akan menghasilkan kesimpulan yang lebih stabil selama tahun 2011-2016.

Penelitian ini akan membahas mengenai pokok yang lebih memiliki relevansi nilai antara laba bersih dengan laba komprehensif pada periode setelah pengimplementasian IFRS ke dalam PSAK. Penelitian ini dilakukan pada perusahaan yang termasuk dalam industri manufaktur di Bursa efek Indonesia (BEI) yang memiliki karakteristik yang cukup beragam dan beperan penting bagi perekonomian. Penelitian ini bertujuan untuk meneliti apakah relevansi nilai relatif laba komprehensif lebih besar dari relevansi nilai relatif laba bersih setelah periode penerapan lanjut IFRS di Indonesia. Hasil penelitian ini diharapkan dapat bermanfaat, khususnya bagi investor untuk mampu memilih informasi akuntansi mana yang lebih relevan dalam penilaian perusahaan. Bagi akuntan, hasil penelitian ini dapat menjadi salah satu masukan dalam evaluasi relevansi informasi akuntansi. Penelitian ini juga diharapkan juga bermanfaat sebagai referensi penelitian.

\section{Telaah Pustaka}

\section{Teori Sinyal}

Teori sinyal berkaitan dengan masalah asimetri informasi yang dapat diantisipasi dengan menyediakan lebih banyak sinyal informasi (Marlinah, 2014). Asimetri informasi dalam pasar terjadi karena manajemen memiliki informasi yang lebih lengkap dibandingkan dengan pihak lain. Permasalahan asimetri informasi tersebut dikurangi melalui sinyal berupa informasi dalam laporan keuangan yang disajikan manajemen (Conelly, Certo, Ireland, \& Reutzel, 2011). Laporan keuangan yang diterbitkan perusahaan seharusnya mengandung informasi yang relevan, andal dan juga merupakan informasi yang dianggap penting oleh investor guna mengevaluasi risiko investasi pada perusahaan (Marlinah, 2014).

Teori sinyal menjelaskan apabila suatu perusahaan menyampaikan informasi keuangan ke pasar modal, maka pasar akan bereaksi atau memberikan respon terhadap informasi tersebut sebagai sinyal yang berpengaruh terhadap nilai suatu perusahaan. Semakin relevan dan transparan suatu informasi yang dipublikasikan, maka diharapkan akan semakin kuat respon pasar terhadap saham perusahaan. 


\section{Relevansi Nilai Relatif Informasi Akuntansi}

Informasi akuntansi yang relevan dapat dipakai investor untuk menentukan harga pasar saham (Kabir \& Laswad, 2011). Selain itu Kargin (2013) juga menyatakan hal yang sama bahwa informasi dalam laporan keuangan dikatakan relevan jika dapat digunakan sebagai dasar prediksi nilai perusahaan. Dengan kata lain, relevansi nilai atas informasi akuntansi didefinisikan sebagai kakteristik pelaporan keuangan yang mensyaratkan bahwa informasi keuangan yang disajikan harus dapat mengubah keputusan pengguna. Pengujian relevansi nilai informasi akuntansi antara laba komprehensif dengan laba bersih pada penelitian ini menggunakan konsep analisis nilai relatif. Nilai relatif merupakan nilai yang membandingkan variabel satu yang berdiri sendiri, dengan variabel lainnya, variabel yang satu bisa lebih dari, kurang dari, atau sama-sama memiliki relevansi nilai (Nugraheni, 2010). Misalnya, laba komprehensif lebih relevan dibandingkan dengan laba bersih atau sebaliknya. Konsep analisis nilai relatif menguji dua variabel independen secara terpisah, dengan melihat apakah kedua variabel independen tersebut mampu memengaruhi variabel dependennya secara individual.

\section{Laba Bersih dan Laba Komprehensif}

Setiap perusahaan melakukan kegiatan operasionalnya guna memperoleh laba. Secara umum, laba dipahami sebagai selisih dari pendapatan atas biayabiayanya dalam periode tertentu (Rejeki \& Warastuti, 2012). Laba dijadikan sebagai indikator kinerja manajemen dalam mengelola sumberdaya yang diamanatkan kepada mereka, serta dapat digunakan untuk melihat prospek perusahaan. Setelah periode konvergensi IFRS, ukuran utama dari kinerja terdiri dari dua indikator yaitu laba bersih dan laba komprehensif. Laba bersih diartikan sebagai penambahan manfaat ekonomi perusahaan selama periode akuntansi berupa kenaikan aset, atau penurunan liabilitas yang mengakibatkan peningkatan ekuitas selain dari setoran penanam modal (Godfrey, Hodgson, Tarca, \& Scott, 2010).

Laba bersih menggambarkan kinerja operasional perusahaan. Sedangkan laba komprehensif diperoleh dengan menggabungkan nilai laba rugi bersih dengan penghasilan komprehensif lain. Informasi pendapatan komprehensif lain semakin penting, seiring dengan semakin kompleksnya bisnis. Oleh karena itu, terdapat pokok lain yang harus dimasukkan dalam laporan laba rugi dan penghasilan komprehensif lain guna memperoleh nilai laba komprehensif yang representatif, antara lain; laba-rugi aktuaria atas program pensiun manfaat pasti, laba rugi revaluasi investasi, laba-rugi lindung-nilai, perubahan surplus revaluasi, laba-rugi translasi mata uang, serta penyesuaian reklasifikasi dan pokok yang material yang membutuhkan pengungkapan terpisah seperti 
penurunan nilai aset, restrukturisasi, penjualan aset, dan sebagainya (Bragg, 2012).

\section{IFRS dan Konvergensi IFRS}

IFRS adalah standar pelaporan keuangan internasional yang disusun oleh International Accounting Standards Board (IASB), yang mencakup standar akuntansi serta standar pelaporan keuangan secara global (Bragg, 2012). Setelah mulai diberlakukannya secara internasional pada tahun 2001, IFRS mulai berkembang di berbagai negara karena mensyaratkan pengungkapan informasi yang lebih luas, sehingga penguna laporan keuangan dapat menharapkan informasi yang relevan. Indonesia sendiri mulai melakukan adopsi IFRS ke dalam PSAK sejak tahun 2008-2012 melalui beberapa tahap.

Penerapan IFRS ke dalam PSAK dilakukan dengan mengeliminasi perbedaan diantara keduanya. Konvergensi IFRS yang dilakukan di Indonesia berperan penting dalam mendukung daya saing perusahaan nasional secara global agar dapat menarik investor, serta dalam rangka untuk menyamaratakan standar secara global agar lebih mudah untuk diperbandingkan. Terdapat perbedaan yang cukup signifikan antara PSAK dan IFRS, PSAK sebelumnya mengacu pada Generally Accepted Accounting Principles (GAAP)Amerika yang bersifat rule based sedangkan IFRS bersifat principle based yang mengatur hal-hal prinsip saja sehingga lebih bersifat fleksibel.

Pada dasarnya dengan IFRS, pengungkapan disyaratkan menjadi lebih luas dan lebih banyak (Kartikahadi, Sinaga, Syamsul, \& Siregar, 2012), sehingga pengungkapan ini dapat membantu pengguna laporan keuangan dalam memperoleh informasi yang memadai. Konvergensi IFRS juga mampu mengakibatkan semakin kuatnya relevansi nilai informasi akuntansi akibat penggunaan nilai wajar, dengan pos/akun dalam laporan keuangan dapat menggambarkan keadaan riil dari ekonomi perusahaan dan mampu mempermudah investor dalam keputusan investasinya.

Penelitian-penelitian terdahulu terkait relevansi nilai informasi akuntansi setelah konvergensi IFRS memberikan hasil bahwa terdapat peningkatan relevansi nilai informasi akuntansi setelah konvergensi IFRS. Tresnaningsih dan Suprihatin (2013) menemukan bahwa relevansi nilai laba meningkat selama tahap lanjut penerapan IFRS. Syagata dan Daljono (2014) membuktikan bahwa relevansi nilai informasi akuntansi berbeda antara periode sebelum dan sesudah dilakukannya konvergensi IFRS. Penelitian yang dilakukan oleh Kristanto (2015) juga memberikan hasil bahwa relevansi nilai informasi akuntansi meningkat pasca adanya konvergensi IFRS. 


\section{Pengembangan Hipotesis}

Dengan diimplementasikannya PSAK 1 (Revisi 2009) pasca konvergensi IFRS, ukuran utama kinerja perusahaan menjadi dua, yaitu laba bersih dan laba komprehensif. Laba komprehensif merepresentasikan kinerja perusahaan setelah digabungkan dengan laba komprehensif lain. Laba atau rugi komprehensif lain merupakan elemen yang berada di luar kendali manajemen serta tidak hanya merepresentasikan kinerja operasional perusahaan. Di sisi lain, laba bersih juga merupakan indikator kinerja suatu perusahaan.

Laba bersih masih menjadi salah satu ukuran utama dalam mengevaluasi kinerja perusahaan dan lebih merefleksikan informasi terkait dengan pengambilan keputusan investor. Laba bersih yang merupakan perwujudan kegiatan operasional perusahaan selama satu periode yang merangkum semua kegiatan perusahaan kemudian dituangkan dalam laporan keuagan mengakibatkan angka laba bersih menjadi perhatian khusus bagi para pengguna laporan keuangan.

Penelitian terdahulu membuktikan bahwa laba bersih memiliki relevansi nilai. Seperti penelitian yang dilakukan oleh Jaweher dan Mounira (2013), serta Tsuji (2013) yang menemukan bahwa laba bersih memiliki hubungan yang kuat dengan harga atau return saham. Penelitian Syagata dan Daljono (2014) yang dilakukan di Indonesia juga menunjukkan bahwa laba bersih memiliki pengaruh yang positif diatas variabel lain yang digunakan dalam penelitian terhadap harga saham. Berdasarkan pemikiran tersebut maka dirumuskan hipotesis:

$\mathrm{H}_{1}$ : Laba bersih memiliki relevansi nilai relatif.

Berbeda dengan laba bersih, pengungkapan laba komprehensif yang meliputi seluruh perubahan pada akiva bersih perusahaan dan membuat manajer mempertimbangkan tidak hanya faktor operasi internal, namun juga faktor eksternal yang mempengaruhi nilai perusahaan membuat laba komprehensif meningkatkan kualitas pelaporan keuangan serta menyediakan informasi yang lebih baik. Laba yang diukur secara komprehensif diharapkan akan merefleksikan kinerja secara lebih baik. Penyajian laba rugi komprehensif diharapkan dapat mempengaruhi pengambilan keputusan keuangan informasi tersebut berhubungan dengan perubahan kemampuan ekonomi secara menyeluruh dan dapat mencerminkan nilai wajar perusahaan. Informasi yang relevan inilah yang akan bermanfaat dalam pengambilan keputusan.

Penelitian terdahulu telah dilakukan untuk menguji relevansi nilai laba rugi komprehensif. Seperti penelitian yang dilakukan oleh Lin, Martinez dan Wang (2016) serta Kanagaretnam, Mathieu dan Shehata (2009) yang menemukan 
bahwa investor secara khusus saat ini lebih menghargai informasi laba rugi komprehensif. Berdasarkan pemikiran tersebut maka dirumuskan hipotesis:

$\mathrm{H}_{2}$ : Laba komprehensif memiliki relevansi nilai relatif.

Penelitian-penelitian terdahulu yang telah membahas mengenai relevansi nilai informasi akuntansi berkaitan dengan penerapan IFRS di Indonesia pada umumnya dilakukan selama proses awal implementasi, sehingga dampak dari konvergensi belum begitu dirasakan. Seperti penelitian Sinarto dan Christiawan (2014) yang menemukan bahwa relevansi nilai laba komprehensif lebih tinggi dibandingkan dengan laba bersih. Penelitian-penelitian tersebut dilakukan pada tahap awal implementasi IFRS, bias jadi pasar bisa jadi terbiasa dengan format pelaporan yang baru. Fenomena ini menjadi menarik karena saat ini penerapan IFRS sudah semakin berkembang.

Penelitian ini berusaha untuk membuktikan bahwa relevansi nilai relatif laba komprehensif lebih besar dari relevansi nilai relatif laba bersih selama tahap lanjut penerapan IFRS ke dalam PSAK tahun 2011-2016. Laba rugi komprehensif memiliki pos-pos pelaporan yang tidak hanya memperlihatkan kinerja perusahaan secara operasional seperti halnya laba bersih, namun juga terdapat pos-pos lain diluar kendali manajemen yang memiliki relevansi nilai (Khan, Bradbury, \& Courtenay, 2017). Beberapa penelitian telah menunjukkan adanya hubungan yang lebih kuat antara pengungkapan komponen pendapatan komprehensif lain dan total laba komprehensif dengan harga atau return saham dibandingkan dengan laba bersih (Devalle, 2012), serta Kanagaretnam, Mathieu dan Shehata (2009). Maka berdasarkan pemikiran tersebut dirumuskan hipotesis:

$\mathrm{H}_{3}$ : Relevansi nilai relatif laba komprehensif lebih besar dari relevansi nilai relatif laba bersih.

\section{Metoda}

\section{Populasi dan Sampel Penelitian}

Penelitian ini menggunakan perusahaan dalam industri manufaktur pada Bursa Efek Indonesia (BEI) tahun 2011-2016 sebagai populasi penelitian. Adapun pemilihan sampel menggunakan teknik purposive sampling, yang menggunakan kriteria-kriteria sebagai berikut: (i) menyediakan data laporan keuangan lengkap per 31 Desember, (ii) terdaftar secara berturut-turut di BEI tahun 2011-2016, (iii) tersedia data harga saham pada 31 Desember tiap tahunnya secara lengkap.

Berdasarkan kriteria diatas maka diperoleh sampel sebanyak 50 perusahaan (300 firm years dalam 5 tahun). Informasi selengkapnya tersaji dalam Tabel 1 . 
Tabel 1. Hasil Seleksi Kriteria Sampel

\begin{tabular}{lc}
\hline \multicolumn{1}{c}{ Keterangan } & Jumlah \\
\hline Perusahaan manufaktur terdaftar pada & \\
Tahun 2011 & 130 \\
Tahun 2012 & 132 \\
Tahun 2013 & 136 \\
Tahun 2014 & 141 \\
Tahun 2015 & 143 \\
Tahun 2016 & 144 \\
Jumlah data firmyear tahun 2011-2016 & 826 \\
Data firmyear yang tidak lengkap selama 6 tahun & -430 \\
Data firmyear yang memiliki nilai ekstrem & -96 \\
Data firmyear secara lengkap tersaji selama 6 tahun dikurangi & 300 \\
nilai ekstrim & \\
Jumlah perusahaan diteliti & 50 \\
\hline
\end{tabular}
Sumber: Data penelitian 2017

\section{Data dan Sumber Data}

Data sekunder dalam penelitian ini bersumber dari laporan keuangan tahunan perusahaan di industri manufaktur yang terdaftar di BEI selama tahun 20112016 yang diperoleh dari laman Bursa Efek Indonesia (www.idx.co.id). Angka laba bersih dan laba komprehensif diambil dari laporan laba rugi dan penghasilan komprehensif lain setiap tahunnya dan variabel harga saham menggunakan harga penutupan saham pada bulan Desember setiap tahun.

\section{Operasionalisasi Variabel Penelitian}

Penelitian ini menggunakan variabel relevansi nilai informasi akuntansi. Relevansi nilai informasi diindikasikan sebagai explanatory power dari informasi akuntansi terhadap nilai perusahaan yang digambarkan dengan harga saham atau return saham. Kekuatan penjelas ini diperoleh dari pengujian regresi dengan variabel bebas (laba bersih atau laba komprehensif) terhadap harga saham (variabel terikat). Relevansi nilai diestimasikan oleh koefisien variabel $(\beta)$, yang menjelaskan tentang seberapa besar koefisien $X$ mampu memengaruhi koefisien $\mathrm{Y}$ di luar pengaruh dari variabel-variabel lain dari fungsi regresi.

Berikut definisi operasional dari variabel-variabel dalam penelitian:

1. Harga Saham (variabel terikat)

Harga saham merepresentasikan harga pasar dari ekuitas perusahaan (Kristanto, 2015). Dengan demikian, efektivitas ukuran kinerja dapat dibuktikan melalui nilai pasar. Data harga saham yang digunakan dalam diperoleh dari harga penutupan setiap tanggal 31 Desember pada tahun $t$. 
2. Laba Bersih (variabel independen)

Laba bersih merepresentasikan kenaikan manfaat ekonomi yang diperoleh dari kegiatan operasional perusahaan. Angka laba bersih dalam penelitian ini diambil dari laporan laba rugi dan penghasilan komprehensif lain pada laporan keuangan perusahaan per tanggal 31 Desember tahun $t$.

3. Laba Komprehensif (variabel independen)

Laba komprehensif adalah total penghasilan bersih perusahaan setelah digabungkan dengan penghasilan komprehensif lain (Bragg, 2012). Angka laba komprehensif dalam penelitian ini dihitung dari laba bersih yang sudah digabungkan dengan komponen penghasilan komprehensif lain yang tidak termasuk dalam kegiatan operasional perusahaan, dan dipisahkan dari entitas pemilik. Sama halnya dengan laba bersih, angka laba komprehensif juga diperoleh dari laporan laba rugi dan penghasilan komprehensif lain pada laporan keuangan perusahaan per tanggal 31 Desember.

\section{Variabel Kontrol}

Penelitian ini menggunakan tiga variabel kontrol yaitu; ROE (Return on Equity), nilai buku ekuitas per lembar saham (BVPS), serta ukuran perusahaan. Variabel-variabel tersebut telah terbukti dalam penelitian terdahulu mampu untuk mempengaruhi harga saham.

1. Return on Equity (ROE)

ROE menunjukkan kemampuan menghasilkan laba bersih dari ekuitas yang dimiliki oleh perusahaan yang dihitung dengan menggunakan formula sebagai berikut:

Return on Equity $=\frac{\text { Laba Bersih }}{\text { Total Ekuitas }}$

2. Nilai Buku Ekuitas per Lembar Saham (BVPS)

BVPS adalah jumlah aset bersih yang dimiliki pemegang saham untuk tiap lembar saham perusahaan (Tresnaningsih \& Suprihatin, 2013) yang dihitung dengan menggunakan formula sebagai berikut:

BVPS $=\frac{\text { Total Ekuitas }}{\text { Jumlah Saham beredar }}$

3. Ukuran Perusahaan

Ukuran perusahaan merupakan variabel yang membantu mengungkapkan kekayaan (aset) perusahaan. Besar kecilnya aset milik perusahaan dapat dijadikan salah satu indikator ukuran perusahaan (Syagata \& Daljono, 2014). Ukuran (size) perusahaan akan diproksikan dengan logaritma natural total aset perusahaan di akhir tahun. 


\section{Teknik Analisis Data}

Model yang dikembangkan untuk menguji seberapa besar relevansi nilai relatif laba bersih dan laba komprehensif terhadap harga saham perusahaan adalah model regresi linier berganda. Untuk menguji H1, H2, dan H3, berikut adalah model yang dikembangkan:

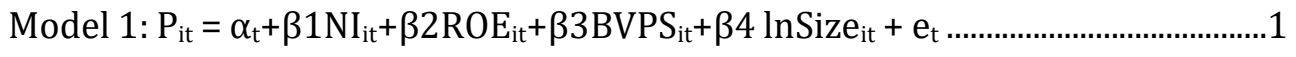

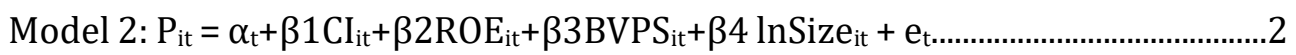

$\mathrm{P}_{\mathrm{it}} \quad=$ Harga saham penutupan perusahaan i pada bulan Desember tahun $\mathrm{t}$

$\alpha \mathrm{t} \quad=$ Konstanta

$\beta=$ Koefisien variabel

$\mathrm{NI}_{\text {it }} \quad=$ Laba bersih perusahaan i pada tahun $\mathrm{t}$

$\mathrm{CI}_{\text {it }} \quad=$ Laba komprehensif perusahaan i pada tahun $\mathrm{t}$

$\mathrm{ROE}_{\mathrm{it}}=$ Variabel kontrol Return on Equity perusahaan i pada tahun $\mathrm{t}$

BVPS $_{\text {it }}=$ Variabel kontrol nilai buku ekuitas per lembar saham perusahaan $\mathrm{i}$ tahun $\mathrm{t}$

Size $_{\text {it }}=$ Variabel kontrol ukuran perusahaan yang diproksikan dengan logaritma natural total aset perusahaan i pada akhir tahun $t$

et $\quad=$ Error

Pengujian Hipotesis 1 melalui Model 1 dibuktikan dengan melihat apakah nilai $\beta 1$ siginifikan atau tidak. Sama halnya dengan Model 2 yang digunakan untuk menguji hipotesis 2 yang dibuktikan dengan melihat apakah nilai $\beta 1$ signifikan atau tidak. Sedangkan untuk menguji hipotesis 3 akan dibandingkan mana yang lebih besar antara $\beta 1$ pada Model 1 dengan $\beta 1$ yang ada pada Model 2 untuk menilai mana yang memiliki pengaruh lebih besar terhadap variabel dependen harga saham. Jika $\beta 1$ pada Model 2 lebih besar daripada $\beta 1$ pada Model 1, maka terbukti secara empiris bahwa relevansi nlai relatif laba komprehensif lebih besar dibandingkan dengan relavansi nilai relatif laba bersih, dan begitu pula sebaliknya.

Sebelum diolah, data terlebih dahulu harus lolos dari uji asumsi klasik, yaitu; uji normalitas, autokorelasi, multikolinearitas, dan heteroskedastisitas. Setelah data dinyatakan bebas dari uji asumsi klasik, uji selanjutnya yang dilakukan yaitu uji hipotesis dengan menggunakan uji signifikansi parsial (uji t) dari kedua model yang ada, uji koefisien determinasi (R2) dan uji keofisien variabel $(\beta)$. 


\section{Hasil dan Pembahasan}

\section{Hasil Penelitian}

Tabel 2 menyajikan statistik deskriptif variabel-variabel dalam penelitian. Berdasarkan statistik deskriptif, penelitian ini menggunakan sampel perusahaan dengan ragam yang bervariasi, baik dari sisi nilai pasar, kinerja maupun ukuran perusahaan. Sampel penelitian terdiri dari perusahaan dengan harga saham sangat rendah hingga sangat tinggi, dengan rata-rata Rp 2.304 dengan variasi yang beragam, ditandai dari standar deviasi Rp 16.008. Begitu pula dengan profil kinerja, laba bersih (NI) serta laba komprehensif (CI), maupun ukuran perusahaan, yang menunjukkan adanya keragaman data.

Tabel 2. Statistik Deskriptif

\begin{tabular}{crrrr}
\hline Variabel & \multicolumn{1}{c}{ Minimum } & \multicolumn{1}{c}{ Maksimum } & \multicolumn{1}{c}{ Rata-Rata } & \multicolumn{1}{c}{ Standar Deviasi } \\
\hline P (Rp) & 25 & 255.000 & 2.304 & 16.088 \\
NI (Rp) & - & 2.171 .608 .000 .000 & 129.681 .421 .330 & 311.848 .937 .362 \\
& 994.406 .551 .920 & - & & \\
CI (Rp) & 994.406 .551 .920 & 2.804 .370 .000 .000 & 146.535 .374 .344 & 335.821 .172 .338 \\
ROE & $-1,24116$ & 1,43533 & 0,1028047 & 0,22467583 \\
BVPS (Rp) & -5.115 & 47.740 & 1.918 & 5.926 \\
Size (Rp) & 7.125 .801 .000 & 19.763 .133 .000 .000 & 2.462 .882 .108 .316 & 3.574 .146 .419 .843 \\
\hline \multicolumn{5}{r}{ Keterangan } \\
P = Harga saham 31 Desember; NI = laba/rugi bersih tahun berjalan; CI = laba rugi komprehensif; \\
ROE = laba bersih yang dihasilkan dari ekuitas perusahaan; BVPS = aset bersih pemilik setiap lembar \\
saham; Size = ukuran perusahaan berdasarkan asset \\
\multicolumn{5}{l}{ Sumber: Data sekunder diolah }
\end{tabular}

Persamaan regresi dalam penelitian ini sudah bebas dari masalah normalitas, autokorelasi, multikolinearitas, dan heteroskedastisitas. Grafik P-P Plot menggambarkan sebaran data residual kedua persamaan model regresi sejajar atau berada di sekitar garis diagonal, sehingga membuktikan bahwa model lolos uji normalitas. Uji autokorelasi untuk setiap model menggunakan uji Durbin Watson, menunjukkan bahwa skor Durbin Watson Model 1 sebesar 1,895 dan Model 2 sebesar 1,960. Setelah dibandingkan dengan batas atas (du) dan batas bawah (dl), disimpulkan bahwa kedua model lolos uji autokorelasi. Skor VIF lebih kecil dari 10 untuk semua variabel dalam kedua model, sehingga disimpulkan bahwa lulus uji multikolinearitas. Uji heteroskedastisitas dengan menggunakan uji Glejser menunjukkan nilai signifikansi data residual semua variabel lebih dari $\alpha=1 \%(0,01)$, sehingga disimpulkan bahwa kedua model penelitian lolos uji heteroskedastisitas.

Model 1 memiliki nilai $\mathrm{R}^{2}$ sebesar 39,9\%, yang berarti bahwa pengaruh variabel bebas di Model 1 terhadap harga saham adalah sebesar 39,9\%, sedangkan sisanya sebesar $60,1 \%$ dipengaruhi oleh faktor lain serta variabel-variabel lain di luar model ini. Berdasarkan Tabel 3, dapat dimaknai bahwa laba bersih 
secara individual berpengaruh positif dan signifikan terhadap harga saham. Artinya, variabel laba bersih secara relatif terhadap variabel lain yaitu ROE, BVPS, dan Size, memiliki kemampuan untuk mempengaruhi harga saham.

Tabel 3. Hasil Pengujian Statistik

\begin{tabular}{|c|c|c|c|c|}
\hline \multicolumn{5}{|c|}{ Model 1} \\
\hline Variabel & $\begin{array}{c}\text { Koefisien Variabel } \\
(\beta)\end{array}$ & $\mathbf{t}$ & Sig. & $\mathbf{R}^{2}$ \\
\hline NI & 0,321 & 4,842 & $0,000^{*}$ & \multirow{4}{*}{0,399} \\
\hline ROE & 1,421 & 3,170 & $0,002 *$ & \\
\hline BVPS & 0,124 & 4,871 & $0,000^{*}$ & \\
\hline Size & 0,128 & 1,396 & 0,164 & \\
\hline \multicolumn{5}{|c|}{ Model 2} \\
\hline Variabel & $\begin{array}{c}\text { Variabel } \\
(\beta)\end{array}$ & $\mathbf{t}$ & Sig. & $\mathbf{R}^{2}$ \\
\hline $\mathrm{CI}$ & 0,353 & 6,019 & $0,000^{*}$ & \multirow{4}{*}{0,430} \\
\hline ROE & 1,626 & 4,143 & $0,001^{*}$ & \\
\hline BVPS & 0,130 & 5,154 & $0,000^{*}$ & \\
\hline Size & 0,077 & 0,876 & 0,382 & \\
\hline \multicolumn{5}{|c|}{$\begin{array}{l}\text { Keterangan: } \mathrm{P}=\text { Harga saham } 31 \text { Desember; } \mathrm{NI}=\text { laba/rugi bersih tahun berjalan; } \mathrm{CI}=\text { laba rugi } \\
\text { komprehensif; ROE = laba bersih yang dihasilkan dari ekuitas perusahaan; BVPS = aset bersih } \\
\text { pemilik setiap lembar saham; Size = ukuran perusahaan berdasarkan aset. *Signifikan pada } \alpha \\
=1 \%\end{array}$} \\
\hline
\end{tabular}

Berdasarkan Tabel 3, nilai $\mathrm{R}^{2}$ pada Model 2 adalah sebesar 43\%, mempunyai arti bahwa pengaruh variabel bebas pada Model 2 terhadap harga saham adalah sebesar $43 \%$, sedangkan sisanya sebesar $57 \%$ dipengaruhi oleh faktor lain di luar model. Selanjutnya dapat disimpulkan juga bahwa variabel laba komprehensif secara individual berpengaruh positif dan signifikan terhadap harga saham. Artinya, variabel laba komprehensif secara relatif terhadap variabel lain yaitu ROE, BVPS, dan Size, memiliki kemampuan untuk mempengaruhi harga saham.

Berdasarkan Tabel 3, bukti menunjukkan bahwa baik variabel laba bersih maupun laba komprehensif sama-sama memiliki pengaruh positif dan signifikan secara relatif terhadap harga saham dengan melihat nilai signifikansi (Sig.) dari keduanya sebesar 0,000 yang lebih kecil dari $\alpha$ 0,01 (1\%). Adapun besarnya pengaruh laba bersih terhadap harga saham adalah sebesar 0,321 atau $32,1 \%$ sedangkan besarnya pengaruh laba komprehensif terhadap harga saham adalah sebesar 0,353 atau 35,3\%. Artinya, setiap terdapat kenaikan laba bersih sebesar Rp1 maka harga saham akan naik sebesar Rp 0,321 dan setiap terdapat kenaikan laba komprehensif sebesar Rp1 maka harga saham akan naik sebsesar Rp 0,353. Hal ini berarti laba komprehensif memiliki pengaruh yang lebih kuat daripada laba bersih. 


\section{Pembahasan}

\section{Relevansi Nilai Relatif Laba Bersih}

Hasil regresi pada Model 1 menunjukkan bahwa Hipotesis 1 dalam penelitian ini didukung oleh data penelitian karena variabel laba bersih berpengaruh siginifikan dengan arah positif terhadap harga saham. Artinya semakin tinggi laba bersih tahun berjalan, maka harga saham juga semakin tinggi. Sebaliknya bila laba bersih yang dilaporkan semakin kecil atau bahkan merugi akan menyebabkan harga saham turun. Hal ini menunjukkan bahwa nilai laba bersih yang dilaporkan oleh perusahaan dalam laporan keuangan mampu mempengaruhi pengambilan keputusan investor dalam menilai perusahaan.

Laba bersih sering dianggap sebagai ukuran terpenting atas kesuksesan atau kegegalan suatu perusahaan. Hasil dari penelitian ini juga memberikan bukti bahwa informasi laba bersih secara individu mampu memberikan pengaruh signifikan terhadap harga saham. Ketika terdapat banyak informasi seperti ROE, BVPS, dan Size, informasi laba bersih masih diperhatikan dan relevan dalam pengambilan keputusan.

Sejalan dengan hal tersebut, laba bersih masih menjadi ukuran utama dan perhatian khusus investor dalam menilai perusahaan. Hal ini dikarenakan harga saham juga dipengaruhi oleh kinerja keuangan suatu perusahaan. Laba bersih mempengaruhi minat investor untuk menanamkan investasi dalam suatu perusahaan, karena jika laba tinggi, maka pembagian dividen juga cenderung meningkat sehingga investor akan lebih berminat untuk melakukan investasi. Syagata dan Daljono (2014) dalam penelitiannya juga membuktikan bahwa laba bersih masih memiliki relevansi nilai relatif di luar variabel nilai buku ekuitas dan ukuran perusahaan. Meskipun terdapat informasi lain dalam laporan keuangan, namun laba bersih masih relevan bagi pengguna laporan keuangan dalam membuat keputusan.

\section{Relevansi Nilai Relatif Laba Komprehensif}

Hasil regresi pada Model 2 menunjukkan bahwa Hipotesis 2 dalam penelitian ini didukung oleh data penelitian karena variabel laba komprehensif berpengaruh siginifikan dengan arah positif terhadap harga saham. Artinya semakin tinggi nilai laba rugi komprehensif maka harga saham juga semakin tinggi. Sebaliknya bila laba komprehensif yang dilaporkan semakin kecil atau bahkan merugi akan menyebabkan harga saham turun. Hal ini menunjukkan bahwa nilai laba komprehesif yang dilaporkan oleh perusahaan dalam laporan keuangan mampu mempengaruhi pengambilan keputusan investor dalam menilai perusahaan. 
Pengungkapan pendapatan komprehensif seharusnya dapat meningkatkan kualitas pelaporan keuangan dan menyediakan informasi yang lebih baik dengan mengkategorikan komponen laba dalam cara yang dianggap bernilai oleh investor. Hasil dari penelitian ini juga memberikan bukti bahwa informasi laba komprehensif secara individu mampu memberikan pengaruh signifikan terhadap harga saham. Ketika terdapat banyak informasi seperti ROE, BVPS, dan Size, informasi laba komprehensif masih diperhatikan dan relevan dalam pengambilan keputusan.

Hasil penelitian ini sejalan dengan penelitian lain yang telah dilakukan sebelumnya seperti Kanagaretnam, Mathieu dan Shehata (2009) serta Lin, Martinez dan Wang, (2016) pada perusahaan di Bursa Efek di Kanada. Penelitian-penelitian tersebut menyatakan bahwa pelaporan laba rugi komprehensif semakin relevansi. Laba rugi komprehensif semakin mampu mengindikasikan seluruh perubahan ekuitas kecuali yang terkait dengan pemilik, membuat laba komprehensif berhubungan sangat erat dengan harga saham dan semakin menjadi perhatian utama investor.

Selain itu hasil penelitian ini juga mendukung pemberlakuan PSAK 1 Revisi 2009 yang mensyaratkan penyajian laba rugi komprehensif. Informasi laba rugi komprehensif yang menganut konsep all-inclusive income mampu memberikan informasi yang menyeluruh dan bermanfaat.

\section{Relevansi Nilai Relatif Laba Komprehensif dan Laba Bersih}

Hasil pengujian regresi yang telah dilakukan pada Model 1 dan Model 2 menunjukkan bahwa Hipotesis 3 didukung oleh data penelitian karena koefisien variabel laba komprehensif pada Model 2 memiliki nilai yang lebih besar dari koefisien variabel laba bersih pada Model 1. Artinya secara relatif variabel laba komprehensif memiliki pengaruh yang lebih besar terhadap harga saham dibandingkan dengan variabel laba bersih. Hal ini menunjukkan bahwa nilai laba komprehesif yang dilaporkan oleh perusahaan dalam laporan keuangan lebih mampu mempengaruhi pengambilan keputusan investor dalam menilai perusahaan dibandingkan dengan laba bersih.

Hasil ini sejalan dengan penelitian-penelitian terkait laba komprehensif yang dilakukan di Indonesia seperti penelitian Sinarto dan Christiawan (2014) yang menggunakan sampel penelitian perusahaan terdaftar di BEI tahun 2011-2013. Penelitian tersebut menunjukkan bahwa pada tahap awal implementasi IFRS, pasar masih belum terbiasa dengan format pelaporan yang baru sehingga evaluasi dalam jangka yang pendek belum mampu menghasilkan keputusan yang stabil dan investor masih menggunakan laba bersih sebagai acuan utama dalam menilai kinerja perusahaan. 
Selama tahap lanjut penerapan IFRS, laba komprehensif berhasil memperoleh perhatian khusus investor karena sifatnya yang sebagai all-inclusive income mampu menyediakan informasi yang menyeluruh dan bermanfaat bagi pengguna laporan keuangan. Laba komprehensif sebagai all-inclusive income memiliki makna bahwa unsur pendapatan yang berada di dalam laba komprehensif mengandung semua informasi mengenai kinerja perusahaan baik itu secara internal (kegiatan operasional) maupun secara eksternal (kinerja perusahaan yang tidak bisa dikendalikan oleh manajeman), sehingga investor saat ini lebih bereaksi terhadap informasi laba komprehensif dalam membantu proses pengambilan keputusannya.

Namun di sisi lain penelitian ini sejalan dengan penelitian-penelitian yang dilakukan di luar negeri seperti Kanagaretnam, Mathieu dan Shehata (2009) serta Lin, Martinez dan Wang (2016) yang menggunakan perusahaan tercatat di Bursa Efek Kanada, dan Devalle (2012) yang menggunakan perusahaan yang tercatat di Bursa Efek di Eropa. Penelitian-penelitian tersebut membuktikan bahwa laba komprehensif memiliki relevansi nilai yang lebih besar dari laba bersih. Hasil tersebut dapat diperoleh karena penelitian-penelitian tersebut dilakukan di Amerika dan Eropa. Amerika mulai menerapkan IFRS pertama kali pada tahun 2001 dan Eropa pada tahun 2005 (Tresnaningsih \& Suprihatin, 2013) sehingga pasar Amerika dan Eropa sudah terbiasa dengan format pelaporan yang baru sesuai IAS 1 dan investor terbukti lebih menghargai informasi dalam laba komprehensif dibandingkan dengan laba bersih.

\section{Simpulan}

Hasil penelitian ini adalah baik laba bersih maupun laba komprehensif berpengaruh secara positif dan signifikan terhadap harga saham. Selain itu, terdapat perbedaan antara pengaruh laba bersih dan laba komprehensif terhadap harga saham. Berdasarkan uji yang sudah dilakukan pada kedua model dapat disimpulkan bahwa laba bersih memiliki relevansi nilai relatif di luar variabel ROE, BVPS, dan ukuran perusahaan. Laba komprehensif memiliki relevansi nilai relatif di luar variabel ROE, BVPS, dan ukuran perusahaan serta relevansi nilai relatif laba komprehensif lebih besar dari relevansi nilai relatif laba bersih. Dengan demikian laba komprehensif dapat menjadi ukuran utama dibandingkan laba bersih dalam mengevaluasi kinerja perusahaan dalam jangka panjang dan lebih merefleksikan informasi terkait dengan pengambilan keputusan investor. Hal ini membuktikan bahwa konsep all-inclusive income dalam laba rugi komprehensif mampu memastikan adanya informasi yang menyeluruh dan bermanfaat.

Secara teoritis, hasil penelitian ini memperkuat penelitian-penelitian yang telah dilakukan di luar negeri seperti penelitian Kanagaretnam, Mathieu dan 
Shehata (2009), Lin, Martinez dan Wang (2016) serta Devalle (2012) yang membuktikan bahwa dalam kondisi penerapan IFRS yang sudah stabil, informasi laba komprehensif lebih dihargai daripada informasi laba bersih. Hasil penelitian ini tidak sejalan dengan penelitian Sinarto dan Christiawan (2014) yang membuktikan bahwa pengaruh laba bersih terhadap harga saham lebih besar daripada pengaruh laba komprehensif terhadap harga saham di masa awal konvergensi IFRS di Indonesia.

Hal yang dapat disarankan dari hasil penelitian ini khususnya bagi investor yaitu sebaiknya ketika ingin membuat keputusan investasi atas dasar angka laba, dapat menggunakan laba komprehensif untuk penilaian kinerja perusahan dalam jangka yang lebih panjang. Hal ini dikarenakan laba komprehensif tidak hanya memperhatikan aspek internal perusahaan yaitu operasional saja, namun juga memperhitungkan aspek lain yang berada di luar kendali manajemen:

Keterbatasan yang ada dalam penelitian ini adalah hanya digunakannya price model untuk mengindikasikan relevansi nilai, dan belum diuji apakah temuan yang dihasilkan dari penelitian ini konsisten jika menggunakan return model, sehingga belum teruji konsistensi relevansi informasi laba bersih dan laba komprehensif jika diukur dengan metode yang berbeda.

Penelitian ini tidak menguji secara spesifik komponen pendapatan komprehensif lain apakah yang paling berpengaruh terhadap harga saham karena hanya menguji relevansi total laba komprehensif saja. Dengan melihat keterbatasan-keterbatasan yang ada pada penelitian ini maka sebaiknya pada penelitian selanjutnya dapat menggunakan model yang lain yaitu return model serta mampu meneliti pada komponen laba komprehensif lain apa yang berpengaruh terhadap return saham.

\section{Daftar Pustaka}

Bragg, S. M. (2012). Panduan IFRS. Jakarta: Indeks.

Conelly, B., Certo, S., Ireland, R., \& Reutzel, C. (2011). Signaling Theory: A Review and Assessment. Journal of Management, 37(1), 39-67. doi:10.1177/0149206310388419

Devalle, A. (2012). Value Relevance of Accounting Data and Financial Crisis in Europe: an Empirical Analysis. International Journal of Accounting and Financial Reporting, 2(2), 201. doi:https://doi.org/10.5296/ijafr.v2i2.2527

Godfrey, J., Hodgson, A., Tarca, A., \& Scott. (2010). Accounting Theory (7 ed.). Australia: John Willey \& Sons Australia Ltd.

Jaweher, B., \& Mounira, B. (2013). Quality of Net Income vs. Total Comprehensive Income in the Context of IAS/IFRS Regulation. International Journal of Finance \& Accounting Studies, 1(2), 17. doi:10.7575/aiac.ijfas.v.1n.2p.17 
Kabir, M., \& Laswad, F. (2011). Properties of net income and total comprehensive income: New Zealand evidence. Accounting Research Journal, 24(3), 268-289. doi:10.1108/10309611111187000

Kanagaretnam, K., Mathieu, R., \& Shehata, M. (2009). Usefulnes of Comprehensive Reporting in Canada. Journal Accounting Public Policy, 28(4), 349-365. doi:https://doi.org/10.1016/j.jaccpubpol.2009.06.004

Kargin, S. (2013). The Impact of IFRS on The Value Relevance of Accounting Inofrmation: Evidence from Turkish Firm. International Journal of Economics and Finance, 5(4), 71. doi:http://dx.doi.org/10.5539/ijef.v5n4p71

Kartikahadi, H., Sinaga, R., Syamsul, M., \& Siregar, S. (2012). Akuntansi Keuangan Berdasar SAK Berbasis IFRS. Jakarta: Salemba Empat.

Khan, S., Bradbury, M. E., \& Courtenay, S. (2017). Value Relevance of Comprehensive Income. Australian Accounting Review, 1. doi:https://doi.org/10.1111/auar.12181

Kristanto, A. (2015). Does IFRS Convergence Promote the Value Relevance of Accounting Information? Jurnal Ekonomi dan Bisnis, 18(1), 19-40. doi:https://doi.org/10.24914/jeb.v18i1.259

Lin, S., Martinez, D., Wang, C., \& Yang, Y.-w. (2016). Is Other Comprehensive Income Reported in the Income Statement More Value Relevant? Journal of Accounting, Auditing \& Finance, 1-23. doi:https://doi.org/10.1177/0148558X16670779

Marlinah, A. (2014). Pengaruh Kebijakan Modal Kerja dan Faktor Lainnya terhadap Profitabilitas Perusahaan Manufaktur. Jurnal Bisnis dan Akuntansi, 16(2), 103.

Nugraheni, B. (2010). Volatilitas Relevansi Nilai Incremental laba dan Nilai Buku. Jurnal Dinamika Akuntansi, 2(2), 83-91. doi:https://doi.org/10.15294/jda.v2i2.1931

Rejeki, T., \& Warastuti, Y. (2012). Pengaruh Perubahan Laba Bersih, Perubahan Laba Komprehensif, dan Perubahan Tingkat Obligasi terhadap Return Saham. Jurnal Akuntansi Bisnis, XI(21), 1.

Sinarto, R., \& Christiawan, J. (2014). Pengaruh Penerapan IFRS terhadap Relevansi Nilai Laba Laporan Keuangan. Tax \& Accounting Review, 4(1), 43.

Syagata, G. S., \& Daljono. (2014). Analisis Komparasi Relevansi Nilai Informasi Akuntansi Sebelum dan Sesudah Konvergensi IFRS di Indonesia. Diponegoro Journal of Accounting, 3(3), 1. Diambil kembali dari https://ejournal3.undip.ac.id/index.php/accounting/article/view/6078

Tresnaningsih, E., \& Suprihatin, S. (2013). Dampak Konvergensi IFRS terhadap Nilai Relevan Informasi Akuntansi. Jurnal Akuntansi dan Keuangan Indonesia, 10(2), 171-183.

Tsuji, C. (2013). Comprehensive Income and Stocl Return: Evidence from the Toyo Stock Exchange. Journal of Management and Sustainability, 3(3), 142. doi:10.5539/jms.v3n3p142 
Yudiman, A., Ahmar, N., \& Darmansyah. (2017). Relevansi Nilai Net Income, Comprehensive Income dan Other Comprehensive Income Pada Perusahaan Manufaktur. Jurnal Ilmiah Profesional Indonesia, 1(1), 1. Retrieved from http://sumateraresearch.org/ojs/index.php/jipi/article/view/8 